\title{
CES
}

COOPERATIVISMO E ECONOMÍA SOCIAL

Núm. 43 (2020-2021), páxs. 323-326

ISSN: 2660-6348

\section{MODIFICACIÓN DA LEY DE COOPERATIVAS DE CANTABRIA}

\author{
MODIFICATION OF THE LAW OF \\ COOPERATIVES OF CANTABRIA
}

Francisco José Torres PÉrez*

Profesor Titular de Dereito Mercantil da Universidade de Vigo. Dirección de correo electrónico: ftorres@uvigo.es 


\title{
RESUMO
}

A Lei de Cooperativas de Cantabria foi promulgada en novembro de 2013 e entrou en vigor o 18 de xaneiro de 2014. Foi a última das normas autonómicas en ser aprobadas e non foi obxecto de grandes modificacións. De feito, nin siquera a norma aquí anotada ten significado unha variación, como veremos, significativa.

Palavras Clave: Cooperativas Cantabria, Consello Economía Social, Órgano administración.

\begin{abstract}
The Law of Cooperatives of Cantabria was promulgated in November 2013 and entered into force on 18 January 2014. It was the last of the regional regulations to be approved and has not been the subject of major changes. In fact, neither the Law commented here has meant a variation, as we shall see, significant.

Keyworlds: Cantabria Cooperatives, Social Economy Council, Administration Body.
\end{abstract}


Na súa exposición de motivos, xustificase tal modificación por dúas razóns. A primeira, o necesario impulso de "Consejo Cántabro" da Economía Social. A respecto, varíase o artigo 143.2 LCC co obxectivo de dar partipación en tal organismo aos axentes sociais mais representativos de dita rexión así como as entidades asociativas da Economía Social en función da súa representatividade e implantación na rexión. Nesa liña, a estrutura orgánica do ciado órgano determínase no precepto citado combinando o perfil político (Presidencia, Vicepresidencia e 4 vogais, dependerán da Consellería competente en materia de Economía Social), con persoas relacionadas co sector da Economía Social, organizacións sindicais e empresariais (12 vogais en total).

II

Ademais do anterior, o obxectivo da norma aquí anotada é modificar certos determinados artigos da LCC coa finalidade de "mellorar a axilidade e eficacia da actuación das Cooperativas". Para iso, varianse mínimamente algúns preceptos da norma orixinaria.

Así, por exemplo, o artigo 16.1 coa nova redacción é totalmente idéntico ao anterior, simplemente requerindo que as persoas designadas pola asamblea que promovan a cooperativa, terán que solicitar ao rexistro de cooperativas a inscrición e acompañar tal solicitude dunha copia da escritura pública -fronte á copia autorizada e copia simple da escritura pública que se requería na redacción orixinaria-.

Nesa alinha tamén refórmase mínimamente o artigo 43.2 LCC, donde recóllese a posibilidade de que estautariamente se prevea para as cooperativas con menos de 10 socios, de nomear a un administrador único ou a dous administradores que poderán actuar solidaria ou mancomunadamente. A diferenza radica en que, na nova redacción, matízase que tal posibilidade de administración deberá figurar estatutariamente.

A reforma, tamén implica engadir un novo apartado ao artigo 43 (o apartado 5). No mesmo matízase o ámbito de representación das persoas que ostenten os cargos de Presidente e Vicepresidente da cooperativa. Tal representación realizarase dentro do ámbito de facultades que lles atribuan os Estatutos e as concretas 
que para a súa execución resulten dos acordos da Asemblea xeral ou do Consello Reitor.

Polo tanto, si analizamos brevemente as dúas modificacións realizadas no artigo 43 LCC, semella, co lexislador cántabro ten como obxectivo o reforzo dos Estatutos como norma fundamental e rectora do funcionamento interno da cooperativa. Non obstante, como fácilmente se pode comprobar, a reforma realizada podería ter tido mais calado para cumprir coa finalidade fixada na exposición de motivos e ao que anteriormente fixemos mención. Neste senso, poderíase ter avanzando nunha modificación real da norma, tal e como se ten feito por outros lexisladores autonómicos, tendente a simplificar o proceso de constitución da cooperativa, ampliar e/ ou revisar as clases de cooperativas existentes ou, entre outras cuestións, reformar aspectos puntuais e conflitivos do rexime económico. 